Berkunsky, I., L. N. Segura, R. A. Ruggera, S. I. K. Faegre, C. Trofino-Falasco, F. López, M. A. Velasco, F. P. Kacoliris, R. M. Aramburú, and J. C. Reboreda. 2017. Reproductive parameters of the Turquoise-fronted Parrot (Amazona aestiva) in the dry Chaco forest. Avian Conservation and Ecology 12(2):6. https://doi.org/10.5751/ACE-01071-120206

Copyright (C) 2017 by the author(s). Published here under license by the Resilience Alliance.

Research Paper

\title{
Reproductive parameters of the Turquoise-fronted Parrot (Amazona aestiva) in the dry Chaco forest
}

Igor Berkunsky ${ }^{1}$, Luciano N. Segura ${ }^{2}$, Román A. Ruggera ${ }^{3}$, Sarah I. K. Faegre ${ }^{4}$, Clara Trofino-Falasco ${ }^{1}$, Fernando G. López $^{5}$, Melina A. Velasco ${ }^{6}$,Federico P. Kacoliris ${ }^{2}$, Rosana M. Aramburú ${ }^{2}$ and Juan C. Reboreda ${ }^{7}$

${ }^{1}$ Instituto Multidisciplinario sobre Ecosistemas y Desarrollo Sustentable, CONICET, Universidad Nacional del Centro de la Provincia de Buenos Aires, ${ }^{2}$ División Zoología Vertebrados, Facultad de Ciencias Naturales y Museo, Universidad Nacional de La Plata, ${ }^{3}$ INECOA-UNJu, CONICET, Facultad de Ciencias Agrarias, ${ }^{4}$ Rota Avian Behavioral Ecology Program, University of Washington, ${ }^{5}$ Centro para el Estudio y Conservación de las Aves Rapaces en Argentina (CECARA), Instituto de Ciencias de la Tierra y Ambientales de La Pampa (INCITAP), Universidad Nacional de La Pampa, ${ }^{6}$ Sección Herpetologia, División Zoología Vertebrados, Facultad de Ciencias Naturales y Museo, Universidad Nacional de La Plata, ${ }^{7}$ Departamento de Ecología, Genética y Evolución \& IEGEBA UBA-CONICET, Facultad de Ciencias Exactas y Naturales, Universidad de Buenos Aires

ABSTRACT. The progressive exploitation and destruction of nesting habitat in recent years, combined with the substantial pressure from legal and illegal removal of wild nestlings and adults, justifies the development of a comprehensive study on the reproductive biology of the Turquoise-fronted Parrot (Amazona aestiva). We analyzed breeding parameters in a wild protected population of Turquoise-fronted Parrots in the Chaco forest, Argentina, examining variation among years, over the course of the breeding season, and in relation to the age of the nest. Mean clutch-size per nesting attempt was 3.68 eggs. Hatching success (proportion of eggs laid that hatch) was 0.73 . Fledging success (proportion of nestlings that fledge) was 0.88 . The overall breeding success (mean number of fledglings per laying female per year) was 0.95 . Clutch size did not vary among years but it decreased with the delay of the nest initiation date. Hatching failure was the greatest cause of egg partial losses, and brood reduction was the main cause of nestling partial loses. Brood reduction was positively correlated with clutch size and with egg-laying date. We did not find interannual variation in any of the clutch or brood size variables. Our results showed that the population of Turquoise-fronted Parrots in the dry Chaco forest has high values of clutch size and nestling survival, and low values of hatching success. However, some aspects of the breeding biology need more attention, especially if the species continues to be harvested.

\section{Paramètres de reproduction de l'Amazone à front bleu (Amazona aestiva) dans la forêt sèche du Chaco}

RÉSUMÉ. L'exploitation et la destruction progressives de l'habitat de nidification advenues ces récentes années, combinées à la pression élevée de captures légale et illégale d'oisillons et d'adultes sauvages, justifient la mise en place d'une étude globale sur la biologie de reproduction de l'Amazone à front bleu (Amazona aestiva). Nous avons analysé les paramètres de reproduction d'une population sauvage protégée de cette amazone dans la forêt du Chaco, en Argentine, examinant les variations interannuelles, tout au long de la saison de reproduction, en relation avec l'âge du nid. La taille moyenne de la ponte par tentative de nidification était de 3,68 oeufs. Le succès d'éclosion (proportion d'oeufs pondus qui ont éclos) était de 0,73 . Le succès à l'envol (proportion de jeunes qui ont pris leur envol) était de 0,88 . Le succès de nidification d'ensemble (nombre moyen de jeunes à l'envol par femelle nicheuse par année) était de 0,95 . La taille de la ponte n'a pas varié d'une année à l'autre, mais était plus faible lorsque la date d'initiation du nid était retardée. L'échec de l'éclosion était la cause la plus importante de perte partielle d'oeufs et une couvée réduite était la cause principale de perte partielle d'oisillons. La couvée réduite était positivement corrélée avec la taille de la ponte et la date de celle-ci. Nous n'avons pas observé de variations interannuelles des variables relatives à la taille de la ponte ou de la couvée. Nos résultats indiquent que la population de l'Amazone à front bleu de la forêt sèche du Chaco montre des valeurs élevées de la taille de ponte et de la survie des oisillons, mais des valeurs faibles du succès d'éclosion. Néanmoins, nous pensons qu'il serait important de se pencher davantage sur certains éléments de la biologie de reproduction de l'espèce, particulièrement si elle continue d'être prélevée.

Key Words: Argentina; Blue-fronted Parrot; breeding ecology; Chaco; Psittaciformes; trade 


\section{INTRODUCTION}

The Psittacidae family has one of the highest proportions of threatened species, with one third of all known parrot species considered at risk (Snyder et al. 2000, Toft and Wright 2015). Sixty-five percent of Neotropical Amazon species are under a category of threat (Birdlife International 2016a). Nest poaching and the capture of adult birds for the pet trade, together with habitat loss due to deforestation, have contributed to the precipitous decline of Amazon parrot populations in Central America, South America, and the Caribbean region (Juniper and Parr 1998, Wright et al. 2001, Clarke and Rolf 2013, Olah et al. 2016). A few wild parrot populations, such as Argentinean Turquoise-fronted Parrots (Amazona aestiva), must also add to their list of threats the trapping for legal markets (Bolkovic and Ramadori 2006). Even when the population trend of Turquoisefronted Parrot appears to be decreasing, the decline is not believed to be sufficiently rapid to approach the thresholds for Near Threatened under the population trend and the species is evaluated as Least Concern (Birdlife International 2016b).

The Turquoise-fronted Parrot is one of most illegal traded parrots in all the countries of its current range, i.e., Argentina, Bolivia, Brazil, and Paraguay (Pires 2012). In Argentina, the legal trapping of Turquoise-fronted Parrots for the live bird trade reached its peak during the 1980s when more than half a million wild individuals were sold on the pet market (Barbarán and Saravia 1997, Rabinovich 2005), placing the Turquoise-fronted Parrot among the most frequently traded Psittacidae species worldwide (Guix et al. 1997). From 1998 until 2012, the National Fauna Authority of Argentina coordinated the removal of more than 20,000 wild nestlings and 5400 wild adults from the Chaco forest in Northern Argentina (Bolkovic and Ramadori 2006). The concept of sustainable wild parrot harvesting was established using removal quotas based on the number of parrots believed to die of natural causes, such as brood reduction and/or predation (Beissinger and Bucher 1992, Stoleson and Beissinger 1997a). Because of the lacking of extensive information, the National Fauna Authority of Argentina estimated harvesting quotas from data of (a) a nonharvested wild Turquoise-fronted Parrot population from Brazilian savannahs and (b) Argentinean government reports (Seixas and Mourao 2002, Rabinovich 2005).

The knowledge on Turquoise-fronted Parrot breeding biology in Chaco forest has been increasing in the last years, and now we have information about its cavity requirements, nest site fidelity, nest survival, and postfledging survival (Berkunsky and Reboreda 2009, Faegre and Berkunsky 2014, Berkunsky et al. 2016). Breeding parameters of the population in Chaco forest are key inputs for the harvesting model, yet little of this information has been published to date. Unfortunately, in the last decades, the Chaco forest had one of the highest deforestation rates in the world; where until 2012, 158,000 $\mathrm{km}^{2}$ of the original habitats of the Chaco were transformed into croplands or pastures (Vallejos et al. 2015). The progressive exploitation and destruction of nesting habitat in recent years, combined with the substantial pressure from legal and illegal removal of wild nestlings and adults, justifies the development of a comprehensive study on the reproductive biology of the Turquoise-fronted Parrot (Berkunsky et al. 2012). We analyzed breeding parameters in a wild protected population of Turquoise-fronted Parrots in the Chaco forest,
Argentina, examining variation among years, over the course of the breeding season, and in relation to the age of the nest. We describe brood reduction and explored how it is affected by clutch size and nest initiation date. Our study provides new and key data about the breeding biology of this exploited species. We hope that this information will allow the Fauna Authorities to refine and/ or reconsider current actions toward a better health of this parrot species, and eventually, for a more sustainable management of their wild populations.

\section{METHODS}

\section{Study area}

We worked in the forest of Loro Hablador Provincial Park $\left(25^{\circ}\right.$ $50^{\prime} \mathrm{S} 61^{\circ} 90^{\prime} \mathrm{W}$ ), a protected area of $300 \mathrm{~km}^{2}$ in the dry Chaco forest of northern Argentina. This dry forest is dominated by two tree species: the white quebracho (Aspidosperma quebracho-blanco) and the red quebracho (Schinopsis lorentzii). The region has a drysubtropical climate (590 $\mathrm{mm}$ average annual rainfall), with a marked seasonality and a long dry season (from April to October). Most of annual rainfall (75\%) occurs from November to March (Huntley and Walker 1982).

\section{Nest monitoring}

Data were collected from early October to late February over five consecutive breeding seasons (2002 to 2006). During each breeding season we intensively searched for Turquoise-fronted Parrot nests by observing the behavior of breeding pairs (Wilson et al. 1995). We used climbing equipment to reach the entrance hole of tree cavities. For details about tree cavities characteristics and cavity reuse, please see Berkunsky and Reboreda (2009). To facilitate the regular inspection of nest contents, most of the nests (94/98) were partially opened by making a hole near the floor of the nest chamber. Most of nests were found for the first time during nestling stage, and inspection holes were opened at that moment. Inspection holes were closed using a concrete lid fixed with wire to the trunk. A concrete lid is a good option to replace the portion of removed tree trunk because it allows isolation from the outside and it is heavy enough to remain in position. We did not have cases where nesting parrots abandoned the nest after the hole was opened. The high nest site fidelity and cavity reuse of Turquoise-fronted Amazon allowed us to work with same cavities for many years (Berkunsky and Reboreda 2009, Berkunsky et al. 2016). Nests were monitored regularly (usually every three days) until the nest failed or the nestlings fledged.

Day 0, i.e., day when the first egg was laid, was determined directly in those nests found before or during the laying stage (considering that parrots lay one egg per day); we began monitoring 82 nests during the egg laying stage. Day 0 of nests found during the incubation or nestling stages were determined by regressive count from the hatching date of the first egg, considering a 28-day incubation period (Berkunsky 2010). When it was not possible to estimate a start date of a nest, i.e., nests that were discovered and lost during the incubation stage, it was excluded from the analysis. The number of active nests varied between years with a range of 16 nests in 2006 and 24 nests in 2005 (Table 1). We estimated the duration of the egg-laying stage as the number of days between the first and the last egg-laying event of the season. 
Table 1. Annual and total values of reproductive parameters and productivity per nesting pair of Turquoise-fronted Parrot (Amazona aestiva) in the dry Chaco Forest, Argentina, 2002-2006. Values represent mean \pm SD (range), n.

\begin{tabular}{|c|c|c|c|c|c|}
\hline Year & $\begin{array}{l}\text { Clutch size at nest } \\
\text { initiation }\end{array}$ & Clutch size at hatching & Brood size hatched & Brood size at fledging & Fledglings per nesting pair \\
\hline 2002 & - & - & $\begin{array}{l}2.20 \pm 0.20 \\
(2-3), 5\end{array}$ & $\begin{array}{c}2.25 \pm 0.66 \\
(1-3), 20\end{array}$ & - \\
\hline 2003 & $\begin{array}{c}3.82 \pm 0.19 \\
(2-6), 22\end{array}$ & $\begin{array}{c}4.00 \pm 0.21 \\
(3-6), 17\end{array}$ & $\begin{array}{c}2.88 \pm 0.24 \\
(1-5), 17\end{array}$ & $\begin{array}{c}2.36 \pm 0.20 \\
(1-3), 11\end{array}$ & $\begin{array}{c}1.37 \pm 1.30 \\
(0-3), 22\end{array}$ \\
\hline 2004 & $\begin{array}{c}3.45 \pm 0.17 \\
(2-5), 20\end{array}$ & $\begin{array}{c}3.19 \pm 0.23 \\
(1-5), 16\end{array}$ & $\begin{array}{c}2.53 \pm 0.29 \\
(1-4), 15\end{array}$ & $\begin{array}{c}2.00 \pm 0.31 \\
(1-3), 7\end{array}$ & $\begin{array}{c}0.80 \pm 1.11 \\
(0-3), 20\end{array}$ \\
\hline 2005 & $\begin{array}{c}3.71 \pm 0.24 \\
(1-6), 24\end{array}$ & $\begin{array}{c}3.45 \pm 0.19 \\
(1-5), 22\end{array}$ & $\begin{array}{c}2.56 \pm 0.26 \\
(1-4), 18\end{array}$ & $\begin{array}{c}2.00 \pm 0.42 \\
(1-4), 8\end{array}$ & $\begin{array}{c}0.65 \pm 1.19 \\
(0-4), 24\end{array}$ \\
\hline 2006 & $\begin{array}{c}3.75 \pm 0.19 \\
(2-5), 16\end{array}$ & $\begin{array}{c}3.56 \pm 0.26 \\
(1-5), 16\end{array}$ & $\begin{array}{c}2.93 \pm 0.27 \\
(1-5), 15\end{array}$ & $\begin{array}{c}2.43 \pm 0.30 \\
(1-3), 7\end{array}$ & $\begin{array}{c}1.06 \pm 1.34 \\
(0-3), 16\end{array}$ \\
\hline $2002-2006$ & $\begin{array}{c}3.68 \pm 0.10 \\
(1-6), 82\end{array}$ & $\begin{array}{c}3.55 \pm 0.11 \\
(1-6), 71\end{array}$ & $\begin{array}{c}2.69 \pm 0.12 \\
(1-5), 70\end{array}$ & $\begin{array}{c}2.23 \pm 0.11 \\
(1-4), 53\end{array}$ & $\begin{array}{c}0.95 \pm 1.24 \\
(0-4), 81\end{array}$ \\
\hline
\end{tabular}

We estimated the duration of the incubation for each egg as the difference between the hatching date and the egg-laying date, and the duration of rearing for each nestling as the difference in days between fledge and hatching dates. Incubation period was estimated for each nest as the number of days elapsed since laying of the last egg until hatching of the last chick, and nestling period as the difference in days between hatching and fledge dates of the first nestling (Nice 1954). Eggs were measured and weighted only during the 2003 and 2004 breeding seasons (37 nests). To avoid pseudo-replicates, we considered only one measurement of egg size and mass per nest, which was obtained by averaging those measurements of all the eggs occurring in a given nest.

We counted eggs and nestlings at four times of the breeding period: (a) at the end of the laying period (total clutch laid), (b) at the end of the incubation period (clutch size at hatching), (c) at the end of hatching (hatched brood size), and (d) immediately before nestlings' fledged (brood size at fledgling). For each nest we also estimated egg survival (the proportion of laid eggs that completed the incubation period), hatching success (the proportion of the eggs that produced nestlings), nestling survival (the proportion of the hatched nestlings that successfully fledged), and fledglings per nesting pair (the number of fledglings per pair who initiated a nesting event).

When partial loses occurred, we recorded the following as the most probable cause: (a) storm (e.g., a flooded cavity, a cavity broken by wind action), (b) predation (i.e., damaged/dead or missing eggs or nestlings, without any apparent cause, or with egg shells or feathers in the nest interior), and (c) dead from unknown causes. In the latter case we distinguished between unhatched eggs (eggs that had not hatched 1 week to 10 days after the expected hatching date) and "dead in nest" (dead nestlings in the nest without any external sign that allowed us to determine the cause of death). Complete losses, i.e., nest failure, were analyzed separately and are not included in this work (Berkunsky et al. 2016).

Most unhatched eggs remained intact inside the nests. In some cases, we removed those eggs to examine the egg contents. We obtained an approximate estimation of infertility as the proportion of unhatched eggs without a visible embryo (Smith and Saunders 1986). This fertility estimation is only an approximation because causes other than infertility can affect the development of an embryo.

\section{Data analysis}

Descriptive statistics represent means $\pm \mathrm{SE}$. We calculated the annual cumulated relative frequency as the percentage of total nests initiated in a given year. We performed all statistical analyses with alpha set to 0.05 , in $\mathrm{R}$ software (R Core Team 2017). Annual differences in reproductive parameters were compared using ANOVA. We used nonparametric (Kruskal-Wallis) analysis of variance to examine whether the average length of the incubation period and the average age of nestlings at fledging varied among years. To analyze the effects of season, standardized laying-date, hatching order, and their interactions over the breeding period we performed a generalized linear model (GLM) analysis, with Poisson error distribution and log link function. To evaluate if brood reduction was associated with clutch size and the laying start date we used a logistic regression.

\section{RESULTS}

Egg laying usually began during the last week of October or first week of November, with slight annual variation, and lasted from six to eight weeks (Fig. 1). The average total clutch laid during our study was $3.68 \pm 0.10$ eggs per clutch $(N=82$ nests), with a range of 1 to 6 and a mode of 4 eggs per clutch (Table 1).

Fig. 1. Temporal distribution of nest initiation of Turquoisefronted Parrot (Amazona aestiva) at Loro Hablador Provincial Park in northern Argentina during the 2002-2006 breeding seasons. Curves represent the cumulated relative frequency of the percentage of total nests initiated in a given year.

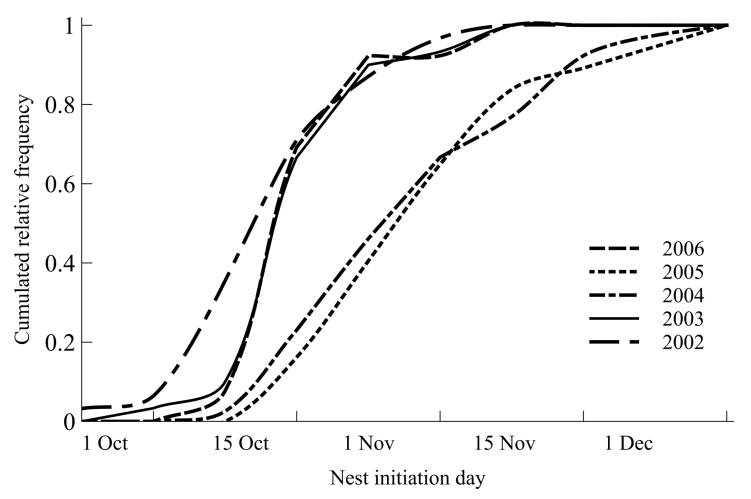


Clutch size decreased with the delay of the laying date (GLM: Standardized laying date Wald $\chi^{2}=6.4, P=0.042$; Fig. 2). Clutch size did not vary among years (GLM: Year Wald $\chi^{2}=4.1, \mathrm{P}=$ 0.13 ). As with most parrot species, eggs were immaculately white. Fresh egg mass averaged $16.8 \mathrm{~g}$ (range 15.1-18.3 g), mean length was $37.3 \mathrm{~mm}$ (range $34.7-38.8 \mathrm{~mm}$ ), and mean width was 29.3 mm (range $27.7-31.7 \mathrm{~mm}, N=17$ nests; Fig. 3).

Fig. 2. Clutch sizes (black dots) of Turquoise-fronted Parrot (Amazona aestiva) nests as a linear function (solid line) of the time of breeding (standardized laying date) during the breeding seasons 2003, 2004, 2005, and 2006 at Loro Hablador Provincial Park in northern Argentina. Dotted lines represent the $95 \%$ confidence interval.

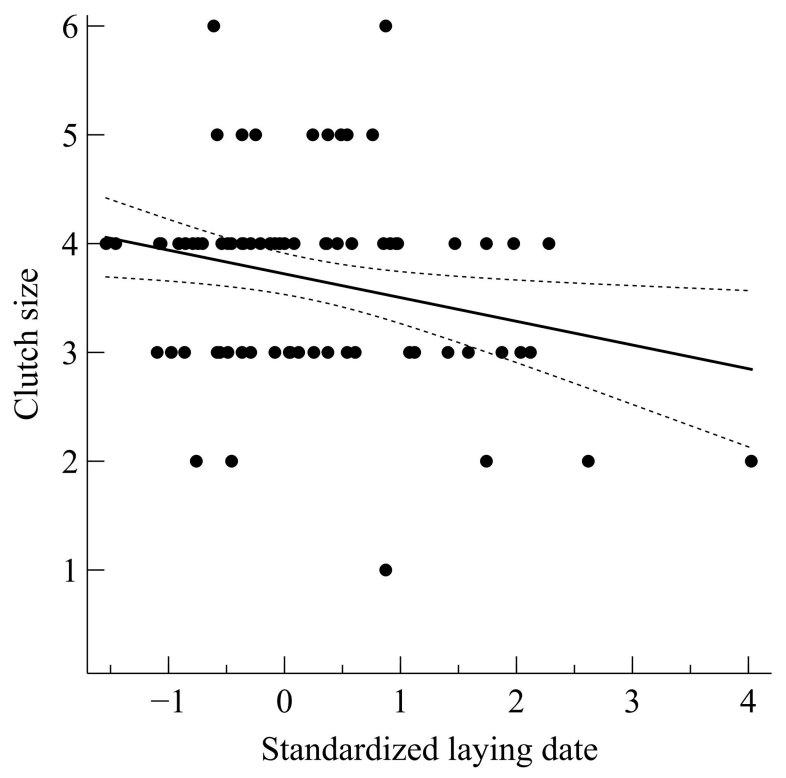

Fig. 3. Means (dots) and SE (lines) of mass (A) and maximum longitude and latitude (B) of Turquoise-fronted Parrot (Amazona aestiva) eggs at Loro Hablador Provincial Park in northern Argentina. Ns are the sample sizes of measured eggs according to their laying order: first egg N1 = 30; second egg $\mathrm{N} 2=32$; third egg N3 = 29; fourth egg N4 = 21; fifth egg N5 = 3 ; and sixth egg N6 = 1).
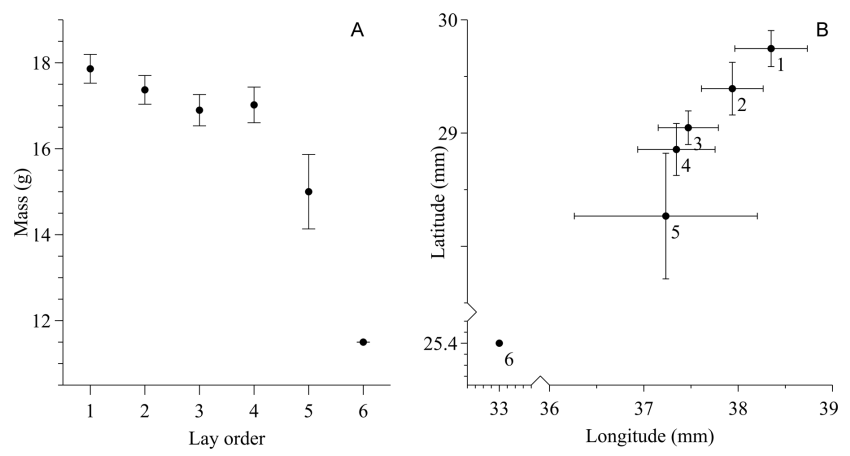

Incubation period was $28.4 \pm 2.1$ days and did not vary among years (Kruskal Wallis: $\chi^{2}=5.8, \mathrm{P}=0.09$ ). Incubation began when the first egg was laid. Egg survival was $0.98 \pm 0.01$ ( $N=69$ nests) and in only two nest a partial loss was observed. In both cases, one egg disappeared during the incubation stage, and we were unable to identify the egg's predator. Hatching success was 0.73 \pm 0.03 ( $N=66$ nests) and was not associated to clutch size (Pearson $r=0.01, \mathrm{P}=0.88)$. Hatching failure was the greatest cause of egg losses. In one-third of nests all eggs hatched (31\%,N=21 nests), while in other nests one egg $(39 \%, N=26$ nests $)$, two eggs $(22 \%$, $N=15$ nests $)$, or three eggs ( $7 \%, N=5$ nests) failed to hatch. Average fertility was $0.73 \pm 0.24$ and only 3 of $17(17 \%)$ of the unhatched eggs that were removed had a partially developed embryo.

The average date of hatch for the first nestling in a nest was 3 December (range: 13 November to 9 January, $N=168$ nestlings). Nestlings hatched asynchronously with an average interval of 1.7 \pm 0.2 days between first and second nestling (range $=0-5$ days, $N=40$ nests), and $2.9 \pm 0.3$ days between second and third nestling (range $=0-8$ days, $N=24$ nests; $\chi^{2}=8.0, \mathrm{P}=0.005$ ). Fledging success was $0.88 \pm 0.04(N=32$ nests). Brood reduction was the main cause of partial loses. Brood reduction was positively correlated with clutch size (Logistic regression coefficient, $b=3.1$ \pm 1.2 ; Fig. 4) and with egg-laying date $\left(b=1.6 \pm 0.7 ; \chi^{2}=16.2\right.$, $\mathrm{P}=0.012$ ). We observed brood reduction in $19 \%$ percent of successful nests (6 of 32 nests). Brood reduction occurred on average at $9.8 \pm 2.1$ days of nestling age ( $N=11$ nestlings) and it was more common at nests where four nestlings hatched $(83 \%$ of clutches with brood reduction) than nests where 3 nestlings hatched ( $7 \%$ of clutches with brood reduction). No poaching events occurred during the period of the study in the monitored nests.

Fig. 4. Brood size of Turquoise-fronted Parrot (Amazona aestiva) as the number of hatched nestlings per nest. Black bars represent the number of nests affected by brood reduction. We observed a positive association between clutch size and brood reduction.

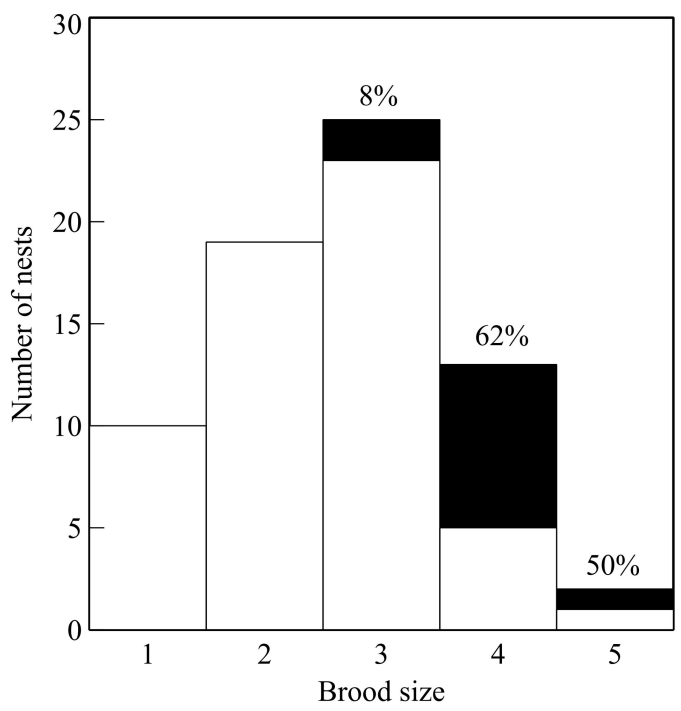


The nestling period lasted around two months (59.4 \pm 0.4 days, $N=32$ nests) and did not vary between years (Kruskal Wallis: $\chi^{2}$ $=8.8, \mathrm{P}=0.10)$. Nestlings fledged asynchronously with an average interval of $2.5 \pm 0.3$ days between first and second $(N=45)$, and $3.1 \pm 0.6$ days between second and third $(N=23)$ nestlings, respectively $\left(\chi^{2}=0.09, P=0.76\right)$. The average fledge date was 28 January (range: 29 December to 22 February). Brood size was positively associated with the duration of the nestling period: the greater the brood sizes, the longer were the extension of the nestling periods (GLM: Clutch size Wald $\chi^{2}=9.1, \mathrm{P}=0.009$; clutch size $\mathrm{x}$ nestling rank, Wald $\chi^{2}=9.5, \mathrm{P}=0.032$ ). The firsthatched individuals in clutches with one or two nestlings left the nest earlier than the first-hatched individuals of clutches with three or four nestlings (Fig. 5).

Fig. 5. Rearing period length (mean \pm SE) as a function of hatching order of nestlings of Turquoise-fronted Parrot (Amazona aestiva) at Loro Hablador Provincial Park in northern Argentina.

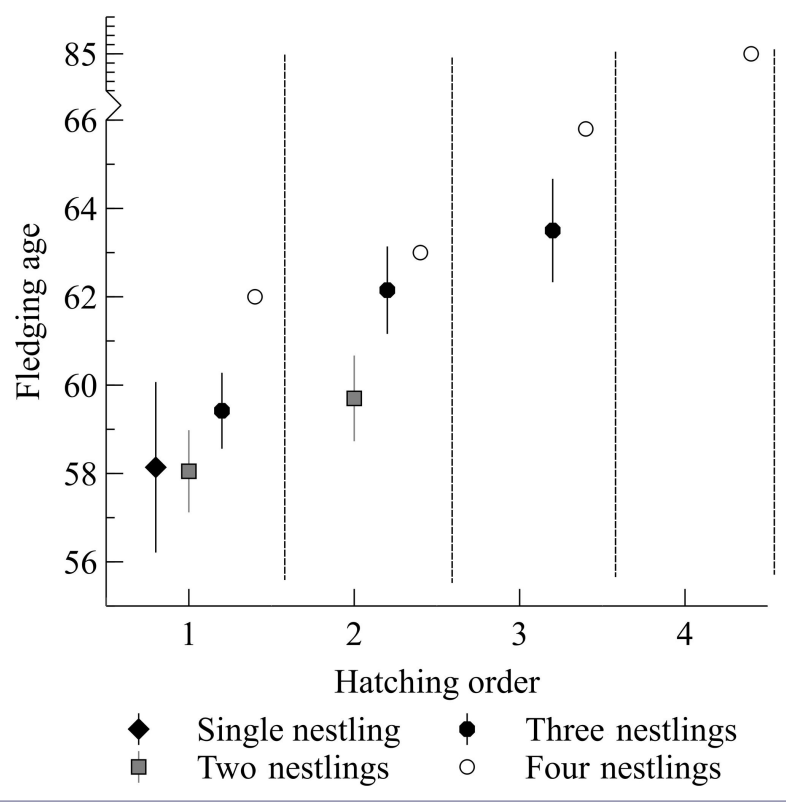

We did not find interannual variation in any of the clutch or brood size variables (ANOVA: Total clutch laid, $\mathrm{F}=1.0$; Clutch size at hatching, $\mathrm{F}=1.0$; Brood size hatched, $\mathrm{F}=1.0$; Brood size at fledgling, $\mathrm{F}=0.7$; Fledglings per nesting pair, $\mathrm{F}=1.3$; all $\mathrm{P} 0.05$ ). Given that the average total clutch was 3.70 eggs per pair, and the average number of fledglings per pair was of 0.95 , each pair lost on average $74 \%$ of its initial reproductive investment.

\section{DISCUSSION}

This is the first long-term study of reproductive ecology of Turquoise-fronted Parrots in Argentina and it is the most complete study conducted do date on this species throughout its entire geographical range. The information gathered during our study indicates that the population of Turquoise-fronted Parrots in the dry Chaco forest has good breeding potential (clutch size and nestling survival are over the mean of the genus). However, some aspects of the breeding biology need more attention, especially if the species continues to be harvested.
The nest initiation of Turquoise-fronted Parrots breeding in Argentina's Chaco forest was highly synchronized among pairs and shifted by only a couple of weeks between years. In all years the initiation of egg laying was most concentrated within a twoweek period. We observed no evidence of a second nesting attempt after a first failed.

Pairs that initiated laying at a later date incurred a cost in terms of clutch size and nestling survival. Nest initiation in the dry Chaco forest could be triggered by weather changes and the resulting change in availability of food resources in this extremely seasonal environment (Marco and Páez 2002). On average, nestlings hatched during early December, with a slight variation between years. This time corresponds with a peak in flowering of trees and shrubs, and an increase in fruit availability, especially those needed to feed the offspring (Berkunsky 2010). If breeding pairs synchronize nestling rearing with seasonal fruit availability, then a delay in nest initiation could compromise the ability of parents to meet the future energetic demands of their nestlings. A shortage of fruits later in the breeding season could explain why clutch size decreased as nests were started later in the season, and why brood reduction was positively related with egg-laying date. The reasons for a delay in clutch initiation by some pairs are unknown, however several possibilities include inexperience, poor body condition of the female, or difficulty finding a suitable nest cavity.

In most species of the Amazona genus the period of nest initiation varies between three to five weeks (Rivera et al. 2013); however, if the frequency distribution of nest initiated is taken into account, a pattern seems to arise in environments with different seasonality (Snyder et al. 1987, Gnam and Rockwell 1991, Enkerlin-Hoeflich 1995). Amazon species from dry tropical forest used to have higher synchrony and nest initiation was concentrated in periods of two to three weeks (Renton and Salinas-Melgoza 1999); instead, Amazon species from Caribbean islands usually have a more extended nest initiation period (Koenig 2001). This could also be attributable to higher fruit diversity and to longer periods of fruit availability in Caribbean islands, compared with dry Chaco forests.

In the dry Chaco forest, Turquoise-fronted Parrots showed a clutch size (3.7 eggs) 37\% larger than the reported value in Brazil, i.e., 2.7 eggs (Seixas and Mourao 2002). This value is the highest reported value in Amazon parrots (Sanz and Rodríguez-Ferraro 2006, Rivera et al. 2013). Egg survival was high, a common observation in Amazon species that could be a consequence of incubation pattern (Renton and Salinas-Melgoza 1999, Koenig 2001, Sanz and Rodríguez-Ferraro 2006). Females only interrupt incubation twice a day, early morning and during the afternoon, and are never far away from the nest (Renton and Salinas-Melgoza 1999, Koenig 2001).

Hatching failures were responsible for most egg losses. A similar case was reported for the Puerto Rican Amazon (Amazona vittata), where hatching failures were the main constraint in breeding success (Beissinger et al. 2008). The hatching success value $(73 \%)$ was less than the majority of reported values for Amazon species (Sanz and Rodríguez-Ferraro 2006, Rivera et al. 2013). Hatching failures could be caused by infertility or death of the embryos (Jamieson 2007). In our study, only $17 \%$ of the unhatched eggs that we removed had partially developed embryos. 
However, because eggs were examined visually without optical elements, we could not identify cases of early embryo death, potentially causing the fertility parameter to be underestimated. Maintaining temperatures within a range necessary for embryonic development and hatching of young may be challenging in the Chaco forest. Cavities must be insulated well enough to avoid exposing eggs to ambient temperatures that can be lethal to embryos, i.e., higher than $40.5{ }^{\circ} \mathrm{C}$ (DuRant et al. 2013). The maximum daily temperature in the study site usually exceeds $40^{\circ}$ $\mathrm{C}$ during the incubation period, and sometimes reaches between $45^{\circ} \mathrm{C}$ and $47^{\circ} \mathrm{C}$ (Berkunsky 2010).

Brood reduction was the main cause of nestling losses and it was positively associated with the number of hatched nestlings and lay date. Brood reduction was mainly observed in four-nestling clutches and was more frequent in later nests. In most cases the last hatched nestling did not survive, and in some cases brood reduction affected more than one nestling. Similar brood reduction was reported in Lilac-crowned Amazon (Amazona finschii), where the younger nestling of four-nestling clutches and sometimes the younger nestling of three-nestling clutches died between six and eight days after hatching (Renton and SalinasMelgoza 2004). Brood reduction was also reported in other Neotropical parrot genera and in all cases survival is lower for the last hatched nestlings (Stoleson and Beissinger 1997b, Masello and Quillfeldt 2002, Vigo et al. 2011).

Partial predation was not an important cause of egg/nestling losses. This is likely because predation events usually affect the whole clutch (Ricklefs 1969). Partial predation events could also be scarce because the most common predators of Turquoisefronted Parrot nests usually consume the whole clutch (Berkunsky et al. 2016).

A variety of parasites can affect nestling survival, especially in those species that tend to reuse cavities every year (Ricklefs 1969). We did not observe partial nestling losses associated with parasites. The number of ectoparasites found in Turquoisefronted Parrot nestlings was low (Berkunsky et al. 2005, Ceballos et al. 2009). We did not find botflies in Turquoise-fronted Parrot nestlings. Interestingly, all nestlings in two Blue-crowned Parakeet nests (Thectocercus acuticaudatus) in our study area were infested with botflies. Botflies can cause serious damage affecting nestling survival in some Neotropical birds (Dudaniec and Kleindorfer 2006, Segura and Reboreda 2011) including parrots, such as the Puerto Rican Amazon (Snyder et al. 1987), the Lilac-crowned Amazon (Renton 2002), and the Scarlet Macaw (Ara macao; Olah et al. 2013). In some Turquoise-fronted Parrot nests we observed green leaves inside the nesting cavity. Secondary compounds present in green leaves could reduce the presence of some ectoparasites (Bucher 1988, Aramburú et al. 2002).

The brood size and hatching order affected the length of the rearing period. The first-hatched individuals in clutches with one or two nestlings left the nest earlier than first-hatched individuals of clutches with three or four nestlings. The magnitude of hatching asynchrony between nestlings was similar to the magnitude of asynchrony between fledgling events within broods. The observed value of 2.2 fledglings per successful nest was very similar to most reported values for Amazona species (Snyder et al. 1987, Enkerlin-Hoeflich 1995, Koenig 2001, Renton and Salinas-Melgoza 2004, Rivera et al. 2013). The survivorship of fledgling Turquoise-fronted Parrots during the first month (i.e., $94 \%$ ) is higher than the survival estimates of other Amazon parrots, as occurs with the Lilac-crowned Parrot (i.e., 73\%) in México and the Puerto Rican Parrot (i.e., 87\%) in the Caribbean (Lindsey et al. 1991, Salinas-Melgoza and Renton 2007, Faegre and Berkunsky 2014).

Although the theoretical concept of sustainable harvest of parrots may be viable, the application must be revised in this particular case where harvesting of nestlings occurs at the end of the nestling stage, when nestlings are between 45 and 60 days old (Bolkovic and Ramadori 2006). All natural reductions in the clutch, such as hatching failures and brood reduction, occur earlier in the nest cycle, during incubation or when nestlings are between 2 and 10 days old. In consequence, the harvested parrots are not individuals that would otherwise die of natural causes. In fact, the reverse is true; they are successful nestlings in nests that have already sustained losses from hatching failures and brood reduction. Future studies are need to determine if the mortality associated with harvesting is compensatory or additive (Burnham and Anderson 1984). We hope that this information will allow the National Fauna Authority to refine and/or reconsider current actions toward species management.

In summary, the breeding behavior of Turquoise-fronted Amazon is generally similar to that of other Amazon parrots for which comparable observations are available (Rivera et al. 2013). The major differences are the large clutch size and the low hatching success, which seems to compensate one to each other, resulting in a number of fledglings per successful nest very similar to other reported values for Amazon parrots. For the first time, we have described brood reduction in Amazon parrots, in the context of parrot harvesting, and we have shown that legally removed nestlings are successful nestlings in nests that have already sustained losses. Further information about the survival of fledglings and adults would be important in testing the effect of harvesting on the Turquoise-fronted Amazon population of the dry Chaco forest.

Responses to this article can be read online at: http://www.ace-eco.org/issues/responses.php/1071

\section{Acknowledgments:}

We are grateful to R. Moncho-Rojas, J. Carrera, B. Charpin, C. de la Fourniére, L. G. Pagano, M. S. López Santoro, K. Jones, H. Povedano, and all volunteers for partnership and collaboration during field and laboratory work. We also thank the Dirección de Fauna, Parques y Ecología of Chaco Province and rangers of Loro Hablador Provincial Park for logistical support. C. T. F., F. L., and M. A. V. were supported by fellowships from Consejo Nacional de Investigaciones Científicas y Técnicas de Argentina (CONICET). I. B., L. N. S., F. P. K., and J. C. R. are Research Fellows of CONICET. This work was supported by Consejo Nacional de Investigaciones Cientificas y Tecnológicas (CONICET PIPS 112-20110-00358, 112-201501-00598CO), Agencia Nacional de Promoción Científica y Tecnológica (PICTs 2011-0173, 2015-2288), Universidad Nacional de La Plata (11/n572, 1/n702), Universidad Nacional del Centro de la Provincia de Buenos Aires, 
IdeaWild, Birder's Exchange, Parrot People Foundation, The World Parrot Trust, The Amazona Society, Parrots International, and individual donations.

\section{LITERATURE CITED}

Aramburú, R., A. Cicchino, and E. Bucher. 2002. Material vegetal fresco en cámaras de cría de la Cotorra Argentina Myiopsitta monachus (Psittacidae). Ornitología Neotropical 13:433-436.

Barbarán, F. R., and C. J. Saravia. 1997. Monitoring an export moratorium of the Blue-fronted Amazon parrot (Amazona aestiva) in Salta Province, Argentina (1992-1996). Vida Silvestre Neotropical 6:3-7.

Beissinger, S. R., and E. H. Bucher. 1992. Can parrots be conserved through sustainable harvesting?: A new model for sustainable harvesting regimes when biological data are incomplete. BioScience 42:164-173. http://dx.doi.org/10.2307/1311821

Beissinger, S. R., J. M. Wunderle Jr, J. M. Meyers, B.-E. Saether, and S. Engen. 2008. Anatomy of a bottleneck: diagnosing factors limiting population growth in the Puerto Rican Parrot. Ecological Monographs 78:185-203. http://dx.doi.org/10.1890/07-0018.1

Berkunsky, I. 2010. Ecología reproductiva del Loro Hablador (Amazona aestiva) en el Chaco Argentino. Dissertation. National University of La Plata, La Plata, Argentina.

Berkunsky, I., A. E. Formoso, and R. M. Aramburú. 2005. Ectoparasitic load of Blue-fronted Parrot (Amazona aestiva, Psittacidae) nestlings. Ornitología Neotropical 16:573-578.

Berkunsky, I., and J. C. Reboreda. 2009. Nest-site fidelity and cavity reoccupation by Blue-fronted Parrots Amazona aestiva in the dry Chaco of Argentina. Ibis 151:145-150. http://dx.doi. org/10.1111/j.1474-919X.2008.00896.X

Berkunsky, I., R. A. Ruggera, R. M. Aramburú, and J. C. Reboreda. 2012. Principales amenazas para la conservación del Loro Hablador (Amazona aestiva) en la Región del Impenetrable, Argentina. Hornero 27:39-49.

Berkunsky I., L. N. Segura, R. M. Aramburú, R. A. Ruggera, W. S. Svagelj, and J. C. Reboreda. 2016. Nest survival and predation in Blue-fronted Parrots Amazona aestiva: effects of nesting behaviour and cavity characteristics. Ardea 104:143-151. http:// dx.doi.org/10.5253/arde.v104i2.a6

Birdlife International. 2016a. IUCN Red List for Birds. Birdlife International, Cambridge, UK. [online] URL: https://www.iucn. org/theme/species/our-work/birds

Birdlife International. 2016b. Amazona aestiva. Birdlife International, Cambridge, UK. [online] URL: http://www. iucnredlist.org/details/22686332/0

Bolkovic, M. L., and D. Ramadori. 2006. Manejo de Fauna Silvestre en la Argentina. Programas de uso sustentable. Dirección de Fauna Silvestre, Secretaría de Ambiente y Desarrollo Sustentable, Buenos Aires, Argentina.

Bucher, E. H. 1988. Do birds use biological control against nest parasites? Parasitology Today 4:1-3. http://dx.doi.org/10.1016/0169-4758 (88) $90045-2$
Burnham, K. P., and D. R. Anderson. 1984. Tests of compensatory vs. additive hypotheses of mortality in mallards. Ecology 65:105-112. http://dx.doi.org/10.2307/1939463

Ceballos, L. A., R. V. Piccinali, I. Berkunsky, U. Kitron, and R. E. Gürtler. 2009. First finding of melanic sylvatic Triatoma infestans (Hemiptera: Reduviidae) colonies in the Argentine Chaco. Journal of Medical Entomology 46:1195-1202. http://dx. doi.org/10.1603/033.046.0530

Clarke, R. V., and A. Rolf. 2013. Poaching, habitat loss and the decline of Neotropical parrots: a comparative spatial analysis. Journal of Experimental Criminology 9:333-353. http://dx.doi. org/10.1007/s11292-013-9177-0

Dudaniec, R. Y., and S. Kleindorfer. 2006. Effects of the parasitic flies of the genus Philornis (Diptera: Muscidae) on birds. Emu 106:13-20. https://dx.doi.org/10.1071/MU04040

DuRant, S. E., W. A. Hopkins, G. R. Hepp, and J. R. Walters. 2013. Ecological, evolutionary, and conservation implications of incubation temperature-dependent phenotypes in birds. Biological Reviews 88:499-509. http://dx.doi.org/10.1111/ brv. 12015

Enkerlin-Hoeflich, E. 1995. Comparative ecology and reproductive biology of three species of Amazona Parrots in Northeastern Mexico. Dissertation. Texas A\&M University, College Station, Texas, USA.

Faegre, S., and I. Berkunsky. 2014. Post-fledging survival of Blue-fronted Parrots (Amazona aestiva). Ornitología Neotropical 25:55-61.

Gnam, R., and R. F. Rockwell. 1991. Reproductive potential and output of the Bahama Parrot Amazona leucocephala bahamensis. Ibis 133:400-405. http://dx.doi.org/10.1111/j.1474-919X.1991. tb04588.x

Guix, J., L. Jover, and X. Ruiz. 1997. Muestreos del comercio de psitácidos neotropicales en la ciudad de Barcelona, España, 1991-1996. Ararajuba 5:156-157.

Huntley, B. J., and B. H. Walker 1982. Ecology of tropical savannas. Springer, Berlin, Germany. http://dx.doi. org/10.1007/978-3-642-68786-0

Jamieson, B. G. M. 2007. Reproductive biology and phylogeny of birds. Part B. Science Publisher, Endfield, New Hampshire, USA.

Juniper, T., and M. Parr. 1998. Parrots: a guide to the parrots of the world. A\&C Black, London, UK.

Koenig, S. E. 2001. The breeding biology of Black-billed Parrot Amazona agilis and Yellow-billed Parrot Amazona collaria in Cockpit Country, Jamaica. Bird Conservation International 11:205-225. https://dx.doi.org/10.1017/S0959270901000284

Lindsey, G. D., W. J. Arendt, W. J. Kalina, and G. W. Pendelton. 1991. Home range and movements of juvenile Puerto Rican Parrots. Journal of Wildlife Management 55:318-322. http://dx. doi.org/10.2307/3809157 
Marco, D. E., and S. A. Páez. 2002. Phenology and phylogeny of animal-dispersed plants in a Dry Chaco forest (Argentina). Journal of Arid Environments 52:1-16. https://dx.doi.org/10.1006/ jare.2002.0976

Masello, J. F., and P. Quillfeldt. 2002. Chick growth and breeding success of the Burrowing Parrot. Condor 104:574-586. https://doi. org/10.1650/0010-5422(2002)104[0574:CGABSO]2.0.CO;2

Nice, M. M. 1954. Problems of incubation periods in North American birds. Condor 56:173-197. https://doi.org/10.2307/1365113 http:// dx.doi.org/10.2307/1365113

Olah, G., S. H. M. Butchart, A. Symes, I. Medina Guzmán, R. Cunningham, D. J. Brightsmith, and R. Heinshon. 2016. Ecological and socio-economic factors affecting extinction risk in parrots. Biodiversity and Conservation 25:205-223. http://dx. doi.org/10.1007/s10531-015-1036-z

Olah, G., G. Vigo, L. Ortiz, L. Rozsa, and D. J. Brightsmith. 2013. Philornis sp. bot fly larvae in free living scarlet macaw nestlings and a new technique for their extraction. Veterinary Parasitology 196:245-249. http://dx.doi.org/10.1016/j.vetpar.2012.12.052

Pires, S. F. 2012. The illegal parrot trade: a literature review. Global Crime 13:176-190. http://dx.doi.org/10.1080/17440572.2012.700180

R Core Team. 2017. R: A language and environment for statistical computing. R Foundation for Statistical Computing, Vienna, Austria. http://www.R-project.org/

Rabinovich, J. E. 2005. Management, precaution and Project Elé: management in the face of multiple uncertainties. Pages 173-188 in R. Cooney and B. Dickson, editors. Biodiversity and the precautionary principle. EarthScan, London, UK.

Renton, K. 2002. Influence of environmental variability on the growth of Lilac-crowned Parrot nestlings. Ibis 144:331-339. http://dx.doi.org/10.1046/j.1474-919X.2002.00015.x

Renton, K., and A. Salinas-Melgoza. 1999. Nesting behavior of the Lilac-crowned Parrot. Wilson Bulletin 111:488-493.

Renton, K., and A. Salinas-Melgoza. 2004. Climatic variability, nest predation, and reproductive output of Lilac-crowned Parrots (Amazona finschii) in tropical dry forest of Western Mexico. Auk 121:1214-1225. http://dx.doi.org/10.1642/0004-8038(2004)121[1214: CVNPAR]2.0.CO;2

Ricklefs, R. E. 1969. An analysis of nesting mortality in birds. Smithsonian Contributions to Zoology 9:1-48. http://dx.doi. org/10.5479/si.00810282.9

Rivera, L., N. Politi, E. H. Bucher, and A. Pidgeon. 2013. Nesting success and productivity of Tucuman Parrots (Amazona tucumana) in high-altitude forests of Argentina: do they differ from lowland Amazona parrots? Emu 114:41-49. https://dx.doi. org/10.1071/MU12062 http://dx.doi.org/10.1071/MU12062

Salinas-Melgoza, A., and K. Renton. 2007. Postfledging survival and development of juvenile Lilac-crowned Parrots. Journal of Wildlife Management 71:43-50. http://dx.doi.org/10.2193/2005-646
Sanz, V., and A. Rodríguez-Ferraro. 2006. Reproductive parameters and productivity of the Yellow-shouldered Parrot on Margarita Island, Venezuela: a long-term study. Condor 108:178-192. http://dx.doi.org/10.1650/0010-5422(2006)108[0178: RPAPOT]2.0.CO;2

Segura, L. N., and J. C. Reboreda. 2011. Botfly parasitism effects on nestling growth and mortality of Red-crested Cardinals. Wilson Journal of Ornithology 123:107-115. http://dx.doi. org/10.1676/10-053.1

Seixas, G. H. F., and G. M. Mourao. 2002. Nesting success and hatching survival of the Blue-fronted Amazon (Amazona aestiva) in the Pantanal of Mato Grosso do Sul, Brazil. Journal of Field Ornithology 73:399-409. http://dx.doi.org/10.1648/0273-8570-73.4.399

Smith, G. T., and D. A. Saunders. 1986. Clutch size and productivity in 3 sympatric species of cockatoo (Psittaciformes) in the southwest of Western Australia. Australian Wildlife Research 13:275-285. https://dx.doi.org/10.1071/WR9860275

Snyder, N., P. McGowan, J. D. Gilardi, and A. Grajal. 2000. Parrots: status survey and conservation action plan 2000-2004. IUCN, Gland, Switzerland.

Snyder, N. F. R., J. W. Wiley, and C. B. Kepler. 1987. The Parrots of Luquillo: natural history and conservation of the Puerto Rican Parrot. Western Foundation of Vertebrate Zoology, Los Angeles, California, USA.

Stoleson, S. H., and S. R. Beissinger. 1997a. Hatching asynchrony, brood reduction, and food limitation in a Neotropical parrot. Ecological Monographs 67:131-154. http:// dx.doi.org/10.1890/0012-9615(1997)067[0131:HABRAF]2.0.CO;2

Stoleson, S. H., and S. R. Beissinger. 1997b. Hatching asynchrony in parrots: boon or bane for sustainable use? Pages 157-180 in J. R. Clemmons and R. Buchholz, editors. Behavioral approaches to conservation in the wild. Cambridge University Press, New York, New York, USA.

Toft, C. A., and T. F. Wright. 2015. Parrots of the wild: a natural history of the world's most captivating birds. University of California Press, Berkeley, California, USA.

Vallejos, M., J. N. Volante, M. J. Mosciaro, L. M. Vale, M. L. Bustamante, and J. M. Paruelo. 2015. Transformation dynamics of the natural cover in the dry Chaco ecoregion: a plot level geodatabase from 1976 to 2012. Journal of Arid Environments 123:3-11. http://dx.doi.org/10.1016/j.jaridenv.2014.11.009

Vigo, G., M. Williams, and D. J. Brightsmith. 2011. Growth of scarlet macaw (Ara macao) chicks in southeastern Peru. Ornitología Neotropical 22:143-153.

Wilson, K. A., R. Field, and M. H. Wilson. 1995. Successful nesting behavior of Puerto Rican parrots. Wilson Bulletin 107:518-529.

Wright, T. F., C. A. Toft, E. Enkerlin-Hoeflich, J. GonzalezElizondo, M. Albornoz, A. Rodríguez-Ferraro, F. Rojas-Suárez, 
V. Sanz, A. Trujillo, S. R. Beissinger, V. Berovides, A. Gálvez, A. T. Brice, K. Joyner, J. Eberhard, J. Gilardi, S. E. Koenig, S. Stoleson, P. Martuscelli, J. M. Meyers, K. Renton, A. M. Rodríguez, A. C. Sosa-Asanza, F. J. Vilella, and J. W. Wiley. 2001. Nest poaching in Neotropical parrots. Conservation Biology 15:710-720. http://dx.doi.org/10.1046/j.1523-1739.2001.015003710. 